\title{
Marius Conkan
}

\section{Mapping Literature: Geocritical Thinking and Posthumanism}

\begin{abstract}
Despite not having the same theoretical background, spatial and posthumanist studies overlap in visions and offer solutions capable of deciphering the new global order and the new human sensibility. Even if geocritical thinkers and specialists on literary geography do not make use of the findings in posthumanism and thinkers on posthumanism seldom refer to spatial and geographic studies, a common ground has indirectly been formed between these two domains. This shared ground is made out of explorations on the new modes of organizing realities and the human elements traversing them. That is why one of the key ideas I want to explore in my study refers to the manner in which recent spatial theories and posthumanist theories share numerous elements capable of clarifying the contradictory and dynamic traits of our current world.
\end{abstract}

Keywords: Posthumanism; Globalization; Geocriticism; Literary Cartography; Chronotope; Possible Worlds; Nomadism.

\section{MARIUS CONKAN}

Babeș-Bolyai University, Cluj-Napoca, Romania mariusconkan@yahoo.com.sg

DOI: $10.24193 /$ cechinox.2018.34.05
The concepts of time and space have crisscrossed theoretical debates, as the latter grew in importance in the second half of the twentieth century. The paradigm of time dominated modernity, whilst, during the same period, space was considered to be a neutral container of socio-political and cultural phenomena. As an expression of human progress (scientific, technological, stressing the ideal(ist) evolution of man), time became hegemonic in philosophical discourse, as space was set aside in the analysis of cultural mutations. Lying at the margin of debate and being insufficiently mapped by anthropology and philosophy, space became a subversive element in the mainstream discourse on human nature. The 1960-70s bear witness to an event of paradigmatic importance known in geography as the spatial turn. ${ }^{1}$ This moment acknowledges and reestablishes the relevance of space in the quest for understanding socio-cultural structures. While in the past the concept of time was considered to be "aristocratic" ${ }^{2}$ and hegemonic, as Michel Foucault $^{3}$ and Bertrand Westphal reveal, space is now being integrated into critical thinking and language. Such an endeavor could also lead to a rearrangement of the human subject. 
Not only social phenomena are being (re)interpreted through methodologies belonging to spatial studies, but also the study of literature has become an object of interest, as literature becomes more relevant in a geopolitical context. It is actually in literary theory that we encounter groundbreaking studies on space, like Gaston Bachelard's topoanalysis and Hugo Diserynck's imagology (1966). All these methods used in dealing with literature have foreseen the importance of geography in the study of literature. The latter is no longer perceived as a purely aesthetic dimension, but rather as an essential component in the context of our globalized world. Therefore literature becomes a major instrument in mapping global societies, but also a strong agent of change. That is why certain research domains like human geography, geocriticism, literary cartography and geography, ecocriticism, postcolonial and decolonial studies etc., divulging their more or less interdisciplinary openness, come together in order to unveil the spatial component of literature and its role in socio-political constructions.

What other roles do time and temporal structures take on inside these new theoretical frameworks? Could dislodging temporality, even if not a permanent one, from some of these methods of analysis reinforce the historical opposition between time and space and institute a supremacy of space (confirmed by its theoretical and political status)? Should we not have overcome such oppositions in the era of heterogeneity and annulment of differences? Various thinkers have unmasked, as already mentioned, the tremendous gravity force around the idea of time in modernity. The same attraction can be also sensed around the idea of space, despite the fact that some researchers use temporality in approaching their geocritical aims. Could it be that we replace a paradigm for another, while the tide has turned against the study of time and we apply, yet again, the same criteria of supremacy for space? Or is it that the newly found importance of place (including existential), or of geography is justified by a completely new understanding of reality? Let us not forget that, once Einstein introduced his revolutionary ideas, space-time turned out to be a compact, non-fragmentary dimension on a mathematical, cosmic and cosmological level. Even Bakhtin's chronotope, ${ }^{4}$ originating in the theory of space-time in physics, is grounded on the same principles regarding narrative fiction, traditionally seen as temporal art. Why is there a dissension between space and time being perpetuated in some theories dealing with the (spatial) matter of both the real world and the one found in literature? Both are subject to change, but also changing and generating new cultural transformations themselves (hence, they find themselves under the sign of temporality and all of its variables).

These are just several questions and hypotheses to start with, as they can be added to a more complex geocritical and mapping endeavor, despite the fact that the temporal element, as I pointed out, emerges in some of the more recent projects on space directed at revealing the structure and role of literature (especially of narrative fictions) in the age of global diversity. That is why the space-time relationship could stop being the source of a theoretical rupture, caused either by a cultural tradition betting on the supremacy of time, or, more recently, on that of space. 
Moreover, spatial-temporal relations could legitimize and lie at the core of overarching and multiperspectival approaches to socio-political and cultural realities. Despite some of the less discussed issues at hand, by applying a multitude of methods (from Robert T. Tally Jr.'s literary cartography $^{5}$ to Bertrand Westphal's geocriticism ${ }^{6}$ and Franco Moretti's quantitative spatial analysis ${ }^{7}$ ), spatial studies showcase exactly the ontological heterogeneity of our current world. Spatial studies cannot remain isolated from other theoretical ventures that set out to clarify the link between the global tectonics and the new image of man protruding out of them. Geocritical and cartographic methods do not make up an exclusive or purely speculative domain for investigating literature and/or social structure. On the contrary, these tools resonate with other philosophical grand projects, exploring, in a pragmatic manner, the current movements of cultural geography.

Despite not having the same theoretical background, spatial and posthumanist studies overlap in visions and offer solutions capable of deciphering the new global order and the new human sensibility. Even if geocritical thinkers and specialists on literary geography do not make use of the findings of posthumanism and thinkers on posthumanism seldom refer to spatial and geographic studies, a common ground has indirectly been formed between these two domains. This shared ground is made out of explorations on the new modes of organizing realities and the human elements traversing them. That is why one of the key ideas I want to explore in my study refers to the manner in which recent spatial theories (engaging not exclusively with literature) and posthumanist theories share numerous elements capable of clarifying the contradictory and dynamic traits of our current world. Geocriticism, literary geography and cartography make use of posthumanist instruments in analyzing literature, despite not focusing on posthuman concerns and topics (such as the rather tense and ever changing relationship between nature and technology).

Posthumanism has not yet acquired a clear definition, as there is a large perspective on how to deal with the nature and effects of globalization, the antropocene, the link between the human, non-human and new scientific discoveries, but also how to treat other facets of a macro-world fueled by and functioning through hybridization. There are numerous attempts to define the posthuman and posthumanism. Some take on a more skeptical tone, others imply and offer positive solutions. All this is a sign that the era of dominant paradigms and visions is long gone, but it also brings to light that a polymorphic and polyphonic process of thinking is more adequate for the global variety it attempts to explore. Each thinker makes his/her personal contribution to the posthumanist debate, even if some ideas seem antithetical. This is but a good sign, in so far as it encourages the conceptual imagination and creativity so necessary in a world reshaping itself from the core. That is why, in a discussion about literature, geography and cartography, I find Rosi Braidotti's arguments useful, as they adhere to the values of critical posthumanism, enabling its definition. As I hope to showcase, posthumanism is a vast philosophical domain, which can encompass some of the most eloquent ideas and defining elements of geocriticism and literary cartography. Therefore, both critical posthumanism and 
geocriticism are complementary theories. Despite dealing with different dilemmas of global existence, they converge on some of the solutions they offer.

In The Posthuman, ${ }^{8}$ Rosi Braidotti identifies the cultural and philosophical transformations of the idea of Man, revealing the primary factors that lead up to the decline of humanism. Individualism, Europocentrism, colonialism, the nature-culture opposition, the radical antithesis of the European ego and Otherness, the spatial/ cultural center and the margin have molded the classical and modern idea of man. But starting with the second half of the twentieth century, all these ideas underwent a complete deconstruction. From this point of view, the posthuman designates new ways of being for Man, in the aftermath of the so-called Death of Man, as an ontological reconfiguration in a hypertechnological world becomes necessary. That is why any sort of radical oppositions, dualities and images of a (self)center mentioned before need to be silenced. These are vital steps in the attempt to define and confine the hybrid, heterogeneous and polymorphic terrain of posthumanism. Whilst Rosi Braidotti's arguments go even further, her expedition into what she calls critical posthumanism tackles and challenges, first and foremost, those ideological forces perpetuating individualism, hierarchies and cultural dichotomies, distances between (pre) established identities and alterity (even non-human), and other similar patterns formatting the humanist paradigm. Distancing herself from values of no significance in our current global community, Braidotti defines the posthuman subject, subjectivity and the posthuman ethics of becoming:
I define the critical posthuman subject within an eco-philosophy of multiple belongings, as a relational subject constituted in and by multiplicity, that is to say a subject that works across differences and is also internally differentiated, but still grounded and accountable. Posthuman subjectivity expresses an embodied and embedded and hence partial form of accountability, based on a strong sense of collectivity, relationality and hence community building. ${ }^{9}$

In our global condition, marked by hybridization, the posthuman subject opposes individualism, as it is non-unitary, relational, multiple and erected beyond differences. It exists solely in connection with the others and, therefore, is localized in relationship with the polymorphic alterity, including non-human. Subjectivity in critical posthumanism is therefore nomadic, "materialist and vitalist, embodied and embedded, firmly located somewhere." 10 Being "relational, 'nature-cultural' and self-organizing," ${ }^{11}$ this subjectivity can be part of the "posthuman recompositions of a panhuman cosmopolitan bond." ${ }^{2}$ As a closing remark, one could say that posthuman ethics are tied to a "process of becoming-minoritarian or becoming-nomad of Europe,"13 and can be defined as: "The project of developing a new kind of post-nationalist nomadic European identity is certainly challenging in that it requires dis-identification from established, nation-bound identities." ${ }^{14}$ That is why critical posthumanism and posthuman sensibility, in Braidotti's terms, are deeply "affirmative." ${ }^{15}$

This would be the theoretical background to start an inquiry into the 
relationship between geography and literature, but also to look into practices deriving from a cartographical approach on narrative spaces. Braidotti's project aims at reorienting global politics to fit the new configuration of the (post)human subject, actively involved in the ethics of becoming-nomad and in a "collective sense of identity." ${ }^{16}$ But her ideas also find an eloquent answer in the spatial practices of literature and criticism in times of globalization.

If spatial theories and practices join critical posthumanism, then we have to return to the founding roots of interpreting literature through the spatial-temporal lens. This is Bakhtin's chronotope, a very useful instrument used even today to explore literary genres. The chronotope describes spatial-temporal relations inside fiction and has, according to Bakhtin, an intrinsic and generic significance. ${ }^{17}$ While these elements were thoroughly explored by literary critics (for example, the chronotopical distribution of genres is the object of recent studies), ${ }^{18}$ Bakhtin's definition entails an extra rendition, quite relevant for the discussion on (post)humanism, geography and literature: "The chronotope as a formally constitutive category determines to a significant degree the image of man in literature as well. The image of man is always intrinsically chronotopic." ${ }^{19}$ Bakhtin reveals, in his description, a fundamental aspect linked to human geography and all of its deriving disciplines: the human subject ("the image of man") is created by space-time, but he also creates spatio-temporalities. This means that geography and the human subject are consubstantial and inter-generative. Moreover, this repetition points to two levels of the relationship between human and space-time: "the image of man in literature" (inside fiction) and "the image of man" (as the real representation, beyond fiction). Both images of the human subject (fictional and real) are chronotopic or spatial-temporally built. But are they inseparable? Are the real chronotopes and fictional ones two distinct, non-relational categories? Or one may find among them a mirror reflecting their structures and properties in a reciprocal manner? These are some of the dilemmas that were sorted out in the coming decades, when the power of fictional spaces to transform images and the structure of real spaces, permanently reshaping the human subject, was noticed through literary geography and geocriticism. Reality becomes a world in the multiverse of possible worlds, the literary text ceases to be self-referential (as it was seen in structuralism) and the fictional worlds are considered to be ontologically valid. ${ }^{20}$ Semantic differences and oppositions between reality and the alterity of fiction are erased, as fictional chronotopes reveal worlds in which elements of reality and human subjectivity are constantly relocated and mapped out.

I have taken this small detour to show how recent spatial theories do not use polarities, dichotomies or hierarchic distributions in exploring the function of literature (hence, of fictional geographies) in the context of global diversity:

At the very start of a new millennium, there is no doubt that literature has to be reinstated within a discourse on the world. What we call "world literature" should imply a double openness on literary productions: first, that they be regarded as wholly universal and freed from any discrimination between 
supposed centers (they always have been plural) and peripheries, and second, that they be linked to "real-life" referents, a coupling that allows them to hold their own position in the global discourse about modern society. ${ }^{21}$

Bertrand Westphal, quoted above, is the founding father of geocriticism, a field dedicated to the exploration of the plural dimension found in the relationship between real and fictional spaces. That is why one of the definitions of geocriticism becomes relevant for the discussion at hand. Geocriticism explores, using interdisciplinarity, global realities placed at the intersection between discourses (political, philosophical), (literary) fictions and (real and imagined) geographies: "Geocriticism will work to map possible worlds, to create plural and paradoxical maps, because it embraces space in its mobile heterogeneity." ${ }^{22}$ Westphal traces, using thorough arguments (displayed in numerous chapters of his book), the most relevant principles of geocriticism. These principles are later summarized in the introduction to a collective volume dedicated to spatial-temporal explorations in literature. ${ }^{23} \mathrm{I}$ will attempt to showcase how these principles of geocriticism include numerous premises found in critical posthumanism. Moreover, this proves how the study of literature, scrutinized by using other tools than traditional ones, can turn into a creative, constructive and pertinent discourse on the current world's complexities and contradictions. In other words, literature and fictional spaces, seen through the lens of geocriticism, overcome their simple aesthetic status and become an important factor in reshaping reality, identities and the (post)human subjectivity. Through this, geocriticism joins other philosophical and social projects set to explain our contemporary world. Let us turn to the principles of geocriticism and discuss their junction with posthumanism:

1. Geocriticism is a geo-centered rather than an ego-centered approach; that is, the analysis focuses on global spatial representations rather than on individual ones (a given traveler's, for example). Thus one may undertake a geocritical study of a city, a region, a territory, and so on, rather than studying a given author's treatment of that place. ${ }^{24}$

In Rosi Braidotti's terms, the posthuman subject rejects self-centered individualism in favor of reconnecting, through a continuous flux, to a multiple alterity. At this point, in Westphal's geocritical terms, the relationship identity-alterity is placed on the level of spatial assemblage, becoming a source for polymorphism and permanent rearrangement of subjects. A pluriperspectival cartography emerges, as the singular outlook on space (a town, region or territory) a writer could draw up is denied. This signals contradictions, tensions and the blank spaces (being cognitively and affectively void) of a global map.

2. Geocriticism ceases to privilege a given point of view in order to embrace a broader range of vision regarding a place. Three main perspectives may be identified (endogenous, exogenous, and allogeneous), and this hybridization of the different focuses (multifocalization) tends to 
relativize Otherness and to identify stereotypes. ${ }^{25}$

This principle, deeply linked to the prior one, tests the quality of the geocritical endeavor and its attempt to integrate differences into a general perspective, characterized by heterogeneity and multiplicity, and not by a unitary view on spatial representations and perceptions. The non-unitary posthuman subject, explored by Braidotti, finds its roots in this polyphonic, hybrid and multifocalized cartography. Following Foucault's arguments, Brian $\mathrm{McHale}$ defines heterotopia as a zone of interference between apparently incompatible possible worlds. ${ }^{26}$ The second principle of geocriticism states the heterotopic feature of this cartography that cancels any radical opposition towards alterity and severs classical dichotomies between a center and a margin. This finding also comes to light in critical posthumanism. Moreover, posthuman subjectivity, as I stated before, is nomadic and this nomadism (also found in Westphal's theory) becomes visible in the circulation of spatial images. The latter, not gravitating around a center, becomes part of hybrid and heterotopic configurations that are in a constant process of alteration. The posthuman subject is neither fix nor stable. As in geocriticism, spatial representations (understood as contexts of subjectivity) are neither immobile nor definitive.

3. Geocriticism promotes the empire of the senses, a polysensuous approach to places - places meaning concrete or realized spaces. Most of the time, places are perceived with our eyes, but it seems most appropriate to diversify sensing to include the sounds, smells, tastes, and textures of a place. ${ }^{27}$

In the first two principles, Westphal describes the geocritical instruments used in portraying the structure of spatial representations. Hybrid points of view (endogenous, exogenous and allogeneous) aim to capture a polyphony of differences, a cartographic multiplicity and to "relativize Otherness." These ideas find, as shown before, their counterpart in critical posthumanism. But the second principle, regarding the nature of space, is placed by Westphal under the sign of polysensoriality. The materialist trait Braidotti attaches to posthuman subjectivity also corresponds to this representation of concrete and material places using our senses. Beyond their abstract, cognitive values, realized spaces (hence, places) are perceived by the human body and become a biorhythmic, localized expression of existence. It is clear that Westphal's geocritical project focuses on combining abstract structures with material ones, real structures with imagined ones (closing on the idea of Edward W. Soja's thirdspace), ${ }^{28}$ so that the whole potential of spatiality can be uncovered. Approaching geography through the senses is already a well-defined research field, as Paul Rodaway states: "Sensuous geography' therefore refers to a study of the geographical understanding which arises out of the stimulation of, or apprehension by, the senses. This is both an individual and a social geography, a physical and a cultural geography." ${ }^{29}$ Geocriticism is, beyond any doubt, a posthuman territory (useful in dealing with our global dimension), due to the fact it situates its discourse beyond any sort of formal or cultural oppositions, 
nesting in a hybrid zone where real, human and perceived spaces merge with fictional and imagined ones.

4. Geocriticism associates both geometric and philosophical coordinates of life - time and space - in a spatiotemporal scheme. A geocritical analysis locates places in a temporal depth in order to uncover or discover multilayered identities, and it highlights the temporal variability of heterogeneous spaces. Spatial analysis reveals that present is asynchronic: our vision of time is not necessarily the same as our neighbor's. Globality implies polychrony. ${ }^{30}$

We thus arrive to the last geocritical principle that encompasses all other principles and, finally, refers to time. Westphal's spatial-temporal blueprint actually shows the pathways Bakhtin's chronotope has followed, in order to be reinterpreted and revised in accordance to our new global contexts. Real and fictional chronotopes make up a hybrid dimension or, in my view, a third chronotope (real and imagined at the same time), in which a new image of man in the world or, in this case, a new image of the posthuman subject emerges. "Multilayered identities," "heterogeneous spaces," "polychrony" are key issues in Braidotti's theory and, despite methodological differences, both critical posthumanism and geocriticism share a common objective: mapping subjectivity in the global era. The ethics of "becoming-nomad" finds its affirmative answer in Westphal's positive outlook on the pragmatic function of geocriticism, but also in his belief that literature can be a discourse of becoming-nomad and impacts the real world:
One of the other issues facing geocriticism is no longer merely to identify the correlation between reality and fiction, between the world and the library, or to consider it as a metaphor, but to come up with a genuine working hypothesis. Since, in terms of representation, fiction is able to influence reality, it is conceivable that literature and other mimetic arts, on the basis of approaches they make possible, could have applications well outside of the fields to which they had traditionally been assigned. Would literary studies be "applicable" to areas outside of the library, or even outside the territories of fiction? In other words, could the study of literature help to decipher the world? I think so. ${ }^{31}$

The posthumanist Weltanschauung finds allies not only in Westphal's geocritical thinking, but also in Robert T. Tally Jr.'s literary cartography. The latter places hybridization and semantic nomadism at the base of a spatial analysis in literature:

I mean to indicate that narratives are in some ways devices or methods used to map the real-and-imagined spaces of human experience. Narratives are, in a sense, mapping machines. On the other hand, narratives - like maps, for that matter - never come before us in some pristine, original form. They are always and already formed by their interpretations or by the interpretative frameworks in which we, as readers, situate them. ${ }^{32}$

On the other hand, Franco Moretti, promoting an applied geocriticism (in 
the area of digital cartography) offers two methods for spatial analysis: "space in literature" and "literature in space." 33 For Moretti, narrative maps are not metaphorical and the mapping process is concrete and grounding: "Placing a literary phenomenon in its specific space - mapping it - is not the conclusion of geographical work; it's the beginning." ${ }^{44}$ Despite all this, Moretti's project is considered by some specialists to be incomplete, as it lacks explorations of the temporal dimension, an aspect that proved quite fruitful in the case of Westphal's geocriticism:

Derek Schilling, for example, in his insightful debunking of Franco Moretti's cartographic project to literally map the nineteenth-century European novel finds time to be the ultimate fly in Moretti's ointment, suggesting that the very idea of mapping fiction ignores the inherently temporal nature of the reading experience. ${ }^{35}$

Contrasting Moretti, Adam Barrow recently deals with the "chronometric imaginary" 36 in literature, indicating new solutions for the cohesion of space and time at the level of interpretation. The theory of Jonathan Flatley can also be placed in a posthumanist frame, as he defines "affective mapping" 37 as rhizomatic (in Deleuze and Guattari's term) and sees it as an effect of defamiliarization (in a formalist acceptance). Finally, all spatial quests, which can be summed up into a blended theory (to use a famous concept introduced by Gilles Fauconnier and Mark Turner), ${ }^{38}$ can serve other future geocritical and posthumanist analysis to better understand the link between reality, fictions and the new condition of man in the global age.

\section{Works Cited}

Bakhtin, Mikhail M., The Dialogic Imagination: Four Essays, Edited by Michael Holquist, Translated by Caryl Emerson and Michael Holquist, Austin, University of Texas Press, 1981/2008

Barrows, Adam, Time, Literature, and Cartography After the Spatial Turn: The Chronometric Imaginary, New York, Palgrave Macmillan, 2016

Bemong, Nele, Pieter Borghart, Michel De Dobbeleer, Kristoffel Demoen, Koen De Temmerman, Bart Keunen (eds.), Bakbtin's Theory of the Literary Chronotope Reflections, Applications, Perspectives, Gent, Academia Press, 2010

Braidotti, Rosi, The Posthuman, Cambridge, Polity Press, 2013

Doležel, Lubomír, Heterocosmica: Fiction and Possible World, Baltimore and London, The John Hopkins University Press, 1998

Fauconnier, Gilles, Mark Turner, The Way We Think: Conceptual Blending and the Mind Hidden Complexities, New York, Basic Books, 2002

Flatley, Jonathan, Affective Mapping: Melancholia and the Politics of Modernism, Cambridge, Harvard University Press, 2008

Foucault, Michel, "Different Spaces," in Essential Works of Foucault (Vol. II):Aesthetics, Method, and Epistemology, Edited by James D. Faubion, Translated by Robert Hurley and others, New York, The New Press, 1988

Hubbard, Phil, Rob Kitchin (eds.), Key Thinkers on Space and Place, London, Sage, 2011/2004

McHale, Brian, Postmodernist Fiction, London and New York, Routledge, 1987/2004

Moretti, Franco, Atlas of the European Novel (1800-1900), London and New York, Verso, 1998 
Pavel, Thomas, Fictional Worlds, Cambridge, Harvard University Press, 1986

Rodaway, Paul, Sensuous Geographies: Body, Sense and Place, London and New York, Routledge, 1994

Soja, Edward W., Thirdspace, Cambridge, Blackwell, 1996

Tally Jr., Robert T. (ed.), Geocritical Explorations: Space, Place, and Mapping in Literary and Cultural Studies, New York, Palgrave Macmillan, 2011

Tally Jr., Robert T. (ed.), Literary Cartographies: Spatiality, Representation, and Narrative, New York, Palgrave Macmillan, 2014

Tally Jr., Robert T., Spatiality, New York, Routledge, 2013

Westphal, Bertrand, Geocriticism: Real and Fictional Spaces, Translated by Robert T. Tally Jr., New York, Palgrave Macmillan, 2011

\section{NoTeS}

1. See Phil Hubbard and Rob Kitchin (eds.), Key Thinkers on Space and Place, London, Sage, 2011/2004.

2. Bertrand Westphal, "Foreword," in Robert T. Tally Jr. (ed.), Geocritical Explorations: Space, Place, and Mapping in Literary and Cultural Studies, New York, Palgrave Macmillan, 2011, p. ix.

3. See Michel Foucault, "Different Spaces," in Essential Works of Foucault (Vol. II): Aesthetics, Method, and Epistemology, Edited by James D. Faubion, Translated by Robert Hurley and others, New York, The New Press, 1988.

4. Mikhail M. Bakhtin, The Dialogic Imagination: Four Essays, Edited by Michael Holquist, Translated by Caryl Emerson and Michael Holquist, Austin, University of Texas Press, 1981/2008.

5. Robert T. Tally Jr., Spatiality, New York, Routledge, 2013.

6. Bertrand Westphal, Geocriticism: Real and Fictional Spaces, Translated by Robert T. Tally Jr., New York, Palgrave Macmillan, 2011.

7. Franco Moretti, Atlas of the European Novel (1800-1900), London and New York, Verso, 1998.

8. Rosi Braidotti, The Posthuman, Cambridge, Polity Press, 2013.

9. Ibidem, p. 49.

10. Ibidem, p. 51.

11. Ibidem, p. 52.

12. Ibidem, p. 53.

13. Ibidem.

14. Ibidem, p. 54.

15. Ibidem.

16. Ibidem, p. 53.

17. Mikhail M. Bakhtin, op. cit., pp. 84-85: "We will give the name chronotope (literally, 'time space') to the intrinsic connectedness of temporal and spatial relationships that are artistically expressed in literature. [...] The chronotope in literature has an intrinsic generic significance. It can even be said that it is precisely the chronotope that defines genre and generic distinctions, for in literature the primary category in the chronotope is time."

18. See Nele Bemong, Pieter Borghart, Michel De Dobbeleer, Kristoffel Demoen, Koen De Temmerman, Bart Keunen (eds.), Bakbtin's Theory of the Literary Chronotope Reflections, Applications, Perspectives, Gent, Academia Press, 2010.

19. Bakhtin, op. cit., p. 85.

20. See Thomas Pavel, Fictional Worlds, Cambridge, Harvard University Press, 1986; Lubomír Doležel, Heterocosmica: Fiction and Possible World, Baltimore and Londra, The John Hopkins University Press, 1998.

21. Westphal, "Foreword," p. xiii.

22. Westphal, Geocriticism: Real and Fictional Spaces, p. 73.

23. Robert T. Tally Jr. (ed.), Geocritical Explorations: Space, Place, and Mapping in Literary and Cultural Studies, ed.cit. 
24. Westphal, "Foreword," p. xiv.

25. Ibidem.

26. Brian McHale, Postmodernist Fiction, London and New York, Routledge, 1987/2004, p. 18: "the sort of space where fragments of a number of possible orders have been gathered together."

27. Westphal, "Foreword," p.xiv.

28. See Edward W. Soja, Thirdspace, Cambridge, Blackwell, 1996.

29. Paul Rodaway, Sensuous Geographies: Body, Sense and Place, London and New York, Routledge, 1994, p. 5.

30. Westphal, "Foreword," p. xiv.

31. Westphal, Geocriticism: Real and Fictional Spaces, p. 169.

32. Robert T. Tally Jr. (ed.), Literary Cartographies Spatiality, Representation, and Narrative, New York, Palgrave Macmillan, 2014, p. 3.

33. Franco Moretti, op. cit., p. 3.

34. Ibidem, p. 7.

35. Adam Barrows, Time, Literature, and Cartography After the Spatial Turn: The Chronometric Imaginary, New York, Palgrave Macmillan, 2016, p. 3.

36. Ibidem.

37. Jonathan Flatley, Affective Mapping: Melancholia and the Politics of Modernism, Cambridge, Harvard University Press, 2008.

38. See Gilles Fauconnier and Mark Turner, The Way We Think: Conceptual Blending and the Mind Hidden Complexities, New York, Basic Books, 2002. 